Indonesian Science Education Research

(ISER)

Available online https://jurnal.unimed.ac.id/2012/index.php/iser

ISSN Online: 2715-4653

\title{
ANALYSIS OF SCIENCES STUDENT PROBLEM SOLVING SKILSS AT JUNIOR HIGH SCHOOL STUDENTS IPA LESSONS \\ Hutagaol M W
}

Department of Science Education Universitas Negeri Medan

Monawahyuni16@gmail.com

Accepted: October $12^{\text {th }}, 2021$. Published: December $31^{\text {th }}, 2021$

\begin{abstract}
The purpose of this study was to analyze the students' science problem solving abilities class IX on dynamic electricity at SMP Negeri 3 Medan. The research method used is descriptive qualitative. In the study, using the subject of 20 students. Technique the sampling used is random sampling. The results showed that. The science problem solving ability of class IX students at SMP Negeri 3 Medan is still classified as low. This can be seen from the acquisition of research results as follows: at the stage identify the problem that is $(33.25 \%)$, the percentage of the total stage of describing the problem is $(35 \%)$, the total percentage of the planning stage of the solution is $(65 \%)$, the total percentage of the stage Implement problem solving solutions, namely (50\%) and indicators Conduct evaluations of (64.50\%). Based on the results of the average score of the five stages, the average score the lowest student's science problem solving ability was at the stage of identifying problem.
\end{abstract}

Keywords: Analysis, Ability, Troubleshooting, Dynamic electricity 


\section{Introduction}

Science education is education that applies hands-on experience to develop students' cognitive by exploring and understanding nature scientifically. Science education is aimed at finding out and doing something so that it helps students to gain a broader understanding of nature, therefore the approach applied in teaching science learning is to combine the experience of science processes and understanding of science products in the form of direct experience (Depdiknas, 2002).

Science is one of the subjects in junior high school students. Science is the result of activities in the form of knowledge, ideas, and concepts that discuss nature and is obtained from a series of experiences through a scientific process. Science learning is not maximized if you only know a product but must be able to understand how the process of making the product is and with that it can be seen the development of students' scientific attitudes in science lessons. (Prihatiningtyas et al., 2013).

Science is a compulsory subject for students, because it provides a lot of experience especially in explaining natural phenomena that are around as well as being able to find solutions to problems in everyday life, but learning science is seen as a complex cognitive activity. Science is considered a complex science, physics contains interesting phenomena and experiments as well as knowledge that is useful for studying nature and the industrial world. The character of science subjects, which are considered complex, raises a lot of anxiety in students, even in every science lesson many students find difficulties in learning science.

In learning science, several concepts are studied, one of which is dynamic electricity. Dynamic electricity is closely related to phenomena or events that are often encountered in everyday life, events and phenomena that are often encountered, for example, an electrical short circuit causing a fire, the use of alternative electrical energy sources and so on. These problems often occur in various places around the world such as the lack of electrical energy supply in remote areas, the number of mall and house fires that are disturbing the community.

Learning in this technical electrical concept requires a variety of science skills, one of which is problem solving skills. Science problem solving ability is a process of eliminating discrepancies that occur from the results obtained. One of the stages of problem solving is making a decision which is the best solution from a number of options provided, inappropriate decision making will affect the quality of the results and problem-solving abilities carried out. A teacher from the beginning trains students on science problem solving skills, to train them by providing science problem solving skills in a continuous way, practicing using problem solving-based questions.

In learning during this pandemic, teachers must be more creative in choosing online media so that learning is more meaningful. By collaborating with various online learning media, it will give students choices and make learning more meaningful (Hardinata A, 2020).

\section{Research Method}

This research was conducted at SMP Negeri 3 Medan in the marijuana semester of the 2020/2021 academic year. The method used in this research is descriptive quantitative method. The subjects in this study were class IX students at SMP Negeri 3 Mean, with 20 students taking the class as the research subject. For the sampling technique, the researcher uses random sampling and the data sources come from students as research subjects.

Table 1. Troubleshooting Indicators by Nitko \& Brookhat

\begin{tabular}{|c|c|}
\hline Indicator & Description \\
\hline $\begin{array}{l}\text { Identify the } \\
\text { problem } \\
\text { (Identify the } \\
\text { problem) }\end{array}$ & $\begin{array}{l}\text { a) determine the problem } \\
\text { b) fact of the cause of the } \\
\text { problem }\end{array}$ \\
\hline $\begin{array}{l}\text { Describe the } \\
\text { problem (Define } \\
\text { and represent } \\
\text { the problem) }\end{array}$ & $\begin{array}{l}\text { a) describe the facts on the } \\
\text { problem in the science } \\
\text { concept } \\
\text { b) Asking question }\end{array}$ \\
\hline $\begin{array}{l}\text { Planning a } \\
\text { solution } \\
\text { (Explore }\end{array}$ & $\begin{array}{l}\text { a) Looking for troubleshooting } \\
\text { solutions } \\
\text { b) Explain some solution } \\
\text { strategies } \\
\text { c) Determine the right } \\
\text { solution } \\
\text { insolution to problem } \\
\end{array}$ \\
\hline $\begin{array}{l}\text { Doing } \\
\text { (Act on } \\
\text { strategies) }\end{array}$ & $\begin{array}{l}\text { a) Give reasons for the solution } \\
\text { used } \\
\text { b) Implementing solutions } \\
\text { using IPA concepts }\end{array}$ \\
\hline
\end{tabular}




\begin{tabular}{|c|c|}
\hline $\begin{array}{l}\text { Carry out } \\
\text { evaluation } \\
\text { (Look back and } \\
\text { evaluate the } \\
\text { effects of your } \\
\text { activities) }\end{array}$ & $\begin{array}{l}\text { a) Evaluating conformity with } \\
\text { the concept } \\
\text { b) Formulate appropriate } \\
\text { conclusions solutionused. }\end{array}$ \\
\hline
\end{tabular}

This study uses the instrument, namely the results of students' science problem-solving ability tests, observation sheets and interview guidelines. The problem-solving ability test used in this study has been validated so that it is ready to be used in research. The data collection method used is the triangulation method, while the data analysis technique uses the Miles and Huberman model. Data analysis activities in the model include data reduction, data presentation, and drawing conclusions (Sugiyono, 2011).

\section{Results and Discussion}

Science problem solving abilities in students who will be studied in this study include identifying problems, describing problems, planning solutions, implementing problem solving solutions, conducting evaluations. The list of names of research subjects obtained in table 2 below:

Table 2. List of research subjects

\begin{tabular}{cc}
\hline No. & Subject Initials \\
\hline 1 & NA \\
\hline 2 & TM \\
\hline 3 & N \\
\hline 4 & SR \\
\hline 5 & JS \\
\hline 6 & JO \\
\hline 7 & PP \\
\hline 8 & FY \\
\hline 9 & FP \\
\hline 10 & FP \\
\hline 11 & QS \\
\hline 12 & MO \\
\hline 13 & JA \\
\hline 14 & ON \\
\hline 15 & RH \\
\hline 16 & RC \\
\hline 17 & RM \\
\hline 18 & GA
\end{tabular}

The research subjects were then given written test questions to determine the students' science problem solving abilities. Then after the written test is carried out, it is followed by an interview test. The data is then described according to problem solving steps, namely identifying problems, describing problems, planning solutions, implementing problem solving solutions, conducting evaluations. Problem solving ability is carried out based on problem solving steps. Furthermore, the data were analyzed based on the average value of the problem-solving indicators. The results are presented in Table 3.

Table 3 Research result

\begin{tabular}{lccc}
\hline $\begin{array}{l}\text { Troubleshooting } \\
\text { Indicator }\end{array}$ & $\begin{array}{c}\text { Total } \\
\text { Valu } \\
\text { e }\end{array}$ & $\begin{array}{c}\text { Aver } \\
\text { age }\end{array}$ & $\begin{array}{c}\% \\
\text { Total }\end{array}$ \\
\hline $\begin{array}{l}\text { Identify the } \\
\text { problem }\end{array}$ & 133 & 6.65 & $33.25 \%$ \\
\hline $\begin{array}{l}\text { Describe the } \\
\text { problem }\end{array}$ & 140 & 7 & $35 \%$ \\
\hline $\begin{array}{l}\text { Planning a } \\
\text { solution }\end{array}$ & 254 & 13 & $65 \%$ \\
\hline $\begin{array}{l}\text { Implementing } \\
\text { problem solving } \\
\text { solutions }\end{array}$ & 200 & 10 & $50 \%$ \\
\hline $\begin{array}{l}\text { Carry out } \\
\text { evaluation }\end{array}$ & 246 & 12.9 & $64.50 \%$ \\
\hline
\end{tabular}

Based on Table 3, it can be seen that the total percentage of scores on the five indicators differs from one another. In Table 3 it is stated that the total percentage of indicators identifying problems is $(33.25 \%)$, the total percentage of indicators describing problems is $(35 \%)$, the total percentage of indicators planning solutions is $(65 \%)$, the total percentage of indicators Implementing problem solving solutions namely $(50 \%)$ and indicators Carry out evaluation by $(64.50 \%)$. This shows that the students' science problem solving ability on the indicators of planning solutions is higher than the students' science problem solving abilities on 
the other four indicators. Meanwhile, the students' science problem solving ability on the indicator of identifying problems is lower than the students' science problem solving ability on the other four indicators. If this happens, it can be seen that the low science problem solving ability of class VII students on dynamic electricity at SMP Negeri 3 Medan is more likely to occur in indicators of identifying problems.

Based on the results of the discussion of the data, it was found that the students' science problem solving ability was assessed through the students' average ability to answer questions on each indicator. From all the results of students' science problem solving abilities, the percentage of the total indicator 'identifying problems' was still relatively low. Meanwhile, the results of students' science problem solving abilities on the total percentage of the 'planning solution' indicator appear to be higher.

To strengthen these results, the analysis was continued with interviews with teachers and students. Based on the results of an interview with one of the science teachers who teaches at SMP Negeri 3 Medan, the teacher said that the students' lack of ability to work on problem-solving questions leads to critical thinking in science which makes students' scores less satisfactory, in science learning students' ability to solve problems is still relatively low, it is proven that when working on questions students tend to directly use mathematical equations without analyzing, guessing formulas and memorizing examples of questions. Students are able to work on simple questions, questions that are only solved through formulas, but when faced with more complex problems students cannot solve the problem.

The learning that takes place is still teacher-centered so that students feel bored and cannot understand the concepts taught by the teacher, as well as the lack of learning by using practicum and online simulations. This is also supported by the results of the author's interviews with students at the school that during their learning they rarely do practicum or online simulations, the teacher in question also said that not doing practicum was constrained by the too short learning time, students said that science was difficult and less interesting. because according to science students, it is inseparable from the formula that must be memorized, this causes students to be less able to solve problems because they are required to always memorize the formula but do not understand the formula.

\section{Conclusion}

Analysis of the science problem-solving abilities of class IX students in the odd semester dynamic electricity material for the 2020/2021 academic year has an average percentage of problem-solving abilities with low criteria on the 'identifying problem' indicator. The lack of students' science problem solving abilities can be caused because students are not familiar with problems that are problem solving so they cannot make problem solving strategies appropriately and have difficulties in solving these problems. These obstacles are due to a lack of student knowledge, students do not understand the problems they have never encountered, and students' lack of interest in science subjects.

\section{Reference}

Hardinata, A., Simatupang, H., Hanifa, F., Latip, A., Efwinda, S., \& Yogica, R. (2020). SURVEY ON THE EFFECTIVENESS OF ONLINE LECTURES DURING COVID-19 PANDEMIC: METHODS AND DIFFICULTIES. ISER (Indonesian science education research), 2(2).

Ministry of National Education. (2002). based curriculum competence (summary of teaching and learning activities). Jakarta: Ministry of National Education.

Ministry of Education and Culture., (2014), Basic framework of the 2013 curriculum, Ministry of Education and Culture, Directorate General of Basic Education, Jakarta.

Nikto, AJ, \& Brookhart, SM (2011). Educational assessment of students. Columbus: Pearson Education, Inc.

Prihatiningtyas, S., Prastowo T and Jatmiko, B. (2013). Implementation of PhET 
simulations and simple kits to teach students psychomotor skills on the subject of optical devices. Indonesian Science Education Journal. 2(1):18-22

Sugiyono. (2011). Qualitative Quantitative
Research Methods and R \& D. Alfabeta: Bandung.

Wahidpur, et al. (2010). Evaluation learning, Yogyakarta:Nuha Litera. 